\title{
Resistance of the insulin crystal to lysosomal proteases: implications for pancreatic B-cell crinophagy
}

\author{
P.A.Halban ${ }^{1}$, R. Mutkoski ${ }^{1}$, G. Dodson ${ }^{2}$ and L.Orci ${ }^{3}$ \\ ${ }^{1}$ Research Division, Joslin Diabetes Center, and Department of Medicine, Brigham and Women's Hospital, Harvard Medical School, Boston, \\ Mass, USA; ${ }^{2}$ Department of Chemistry, University of York, UK, \\ ${ }^{3}$ Institute of Histology and Embryology, University of Geneva School of Medicine, Geneva, Switzerland
}

Summary. Insulin is thought to be chemically stabilized within $\beta$-granules in the crystal form. The other major products of the $\beta$-granule, proinsulin and C-peptide, by contrast, are not thought able to crystallize. The physico-chemical properties of peptides in soluble or crystalline form are dramatically different. The ability of insulin to crystallize in the $\beta$-granule might thus explain why this peptide, but not proinsulin/Cpeptide, remains stable even after its introduction into lysosomes as occurs during granulolysis (crinophagy). We have now studied this by exposing proinsulin or insulin to lysosomal proteases in vitro. ${ }^{125} \mathrm{I}$-insulin in soluble form was found to be degraded at the same rate as ${ }^{125}$ I-proinsulin.
Strikingly, however, when the labelled insulin was crystallized, its rate of degradation was decreased from 1.9 to $0.2 \mathrm{pmol} / \mathrm{min}$. We take these data as confirmation that the insulin crystal is resistant to degradation, thereby possibly accounting for (a) the presence of insulin immunoreactivity within multigranular bodies, and (b) the unusually slow rate of degradation of insulin within B cells compared with that of other hormones in their cells of origin.

Key words: Insulin, proinsulin, crinophagy, insulin crystals, degradation, lysosomes.
The degradation of hormones stored within their cell of origin appears to be a pathway shared by many endocrine cell types [1]. For the insulin secreting B cells, degradation of insulin stores was first suggested morphologically $[2,3]$ and subsequently confirmed biochemically [4]. Granulolysis or crinophagy [5], i.e. the fusion of secretory granules with primary lysosomes to yield secondary lysosomes where the hormonal content is degraded, is one possible pathway for such degradation; indeed, this pathway is active in the B cell [2, $3,6]$.

We have previously suggested that the ability of insulin to crystalize may affect its subsequent handling within the B cell [6]. In particular, it is possible that the crystal form may prevent the normally rapid degradation of a hormone expected within lysosomes. We therefore wished to establish whether (a) proinsulin and insulin in soluble form are degraded by lysosome proteases, (b) the insulin crystal is stable in an environment suitable for optimal lysosomal enzyme activity, and (c) insulin degradation by lysosomal proteases is inhibited if it is crystalline.

\section{Materials and methods}

\section{Lysosomes}

Isolation. Lysosomes were isolated and purified from adult male rat livers through differential and sucrose gradient centrifugation [7]. The final pellet, considered in the original procedure [7] to consist of pure lysosomes, was found to be comprised of two different materials. One was brown and adhered to the centrifuge tube, whereas the other was a pink layer of material which could be readily suspended. Assay of aryl sulfatase activity and of proteolytic activity at acid $\mathrm{pH}$ showed the brown layer to be more active than the pink material, which was thus flushed with a gentle stream of $0.25 \mathrm{~mol} / 1$ sucrose in phosphate buffer. The brown layer only was used for the experiments.

The purified lysosomes were suspended in citrate/BSA buffer pH $5.0[4.5 \mathrm{mmol} / 1$ citrate, $103 \mathrm{mmol} / 1$ disodium phosphate, $0.5 \mathrm{mg} / \mathrm{ml}$ bovine serum albumin (BSA)] and freeze-thawed five times (successive freezing on liquid $\mathrm{N}_{2}$ followed by thawing at $15^{\circ} \mathrm{C}$ ) to disrupt the lysosomal membranes and solubilize lysosomal proteases. When the total protein content of the lysosomal preparation was to be measured, BSA was omitted from the buffers. The protease solution was then kept in small aliquots at $-70^{\circ} \mathrm{C}$. Usually, lysosomes from two livers were disrupted and their contents dissolved in $4 \mathrm{ml}$ citrate/BSA. For each assay point (see below), this solution was diluted by adding an equal volume of citrate/BSA and $10 \mu \mathrm{l}$ of the dilute solution then used. 
Morphology. Lysosomes destined for morphology were fixed directly after the isolation procedure (without prior freeze-thawing), in $2 \%$ phosphate-buffered ghtaraldehyde for $30 \mathrm{~min}$ at room temperature and then washed three times in phosphate buffer. For conventional electron microscopy, post fixation was carried out in 1\% phosphatebuffered osmium tetroxide followed by ethanol dehydration and Epon embedding. For immunocytochemistry, post fixation was omitted and embedding was carried out at low temperature in Lowicryl $\mathrm{K}_{4} \mathrm{M}$ resin [8]. Thin sections were prepared from the embedded material and observed, after uranyl acetate and lead citrate contrasting, in a Philips EM 300 electron microscope. The post embedding protein A-gold method [9] was used for immunocytochemical demonstration of a lysosomal enzyme, cathepsin B (anti-cathepsin B was a generous gift of Dr. N. Katunuma, Tohushima, Japan) or of insulin (guinea-pig antiporcine insulin serum was provided by Dr. P. H. Wright, Indianapolis, Ind, USA).

Enzyme activity. Aryl sulfatase, used as a marker enzyme for lysosomes, was assayed colorimetrically [10]. Total protein in samples was assayed using a commercially available colorimetric kit (Biorad), which uses Coomassie G-250 as the dye reagent. Bovine serum albumin was used as the protein standard.

\section{Insulin crystals}

Radiolabelled insulin $\mathrm{Zn}$-hexamer crystals were prepared according to the crystallization method of Schlichtkrull (11) with some modifications. Pork insulin (Eli Lilly, Indianapolis, Ind, USA) was dissolved in $0.02 \mathrm{~mol} / 1 \mathrm{HCl}$ to obtain a $10 \mathrm{mg} / \mathrm{ml}$ solution. The following were then mixed sequentially in a glass tube: $150 \mu 1$ insulin solution, $15 \mu \mathrm{l} 0.12 \mathrm{~mol} / 1$ zinc sulfate, $75 \mu \mathrm{l} 0.2 \mathrm{~mol} / 1$ sodium citrate, $20 \mu \mathrm{l} \mathrm{A} \mathrm{A}^{14}$-mono ${ }^{125} \mathrm{I}$-insulin (human, specific activity $365 \mu \mathrm{Ci} / \mu \mathrm{g}$, $30.8 \mu \mathrm{Ci} / \mathrm{ml}$ concentration). Crystals were grown at $2-4^{\circ} \mathrm{C}$ and without acetone. After 4 days, the crystals were harvested by centrifugation and washed $3 \times$ in citrate/BSA containing $7.5 \mathrm{mmol} / \mathrm{I}$ zinc sulfate (citrate/BSA $/ \mathrm{Zn}^{++}$). The percentage of unlabelled insulin in the crystal form was assessed by measuring the insulin concentration by ultraviolet absorption in the solution before and after crystallization. ${ }^{125} \mathrm{I}$-insulin incorporation was determined by measuring the radioactivity in the supernatant and crystals. Both native and iodinated insulin were found $>90 \%$ in the crystal form. Stability of the crystals over time was monitored by measuring the ratio of radioactivity in soluble and crystalline forms. No significant solubilization of the crystals was observed at $2-4^{\circ} \mathrm{C}$ over a period of weeks and the crystals were stable by this criterion for $>2 \mathrm{~h}$ at $37^{\circ} \mathrm{C}$ in citrate/BSA $\mathrm{Zn}^{++}$.

To prepare microcrystals, crystals as prepared above were suspended in $10 \mathrm{ml}$ citrate/BSA $/ \mathrm{Zn}^{++}$in a 25 -ml glass beaker and then stirred with a magnetic bar for $20 \mathrm{~min}$. This treatment resulted in disruption of the crystals. Crystals were then sized using a light microscope with a measuring grid.

\section{Insulin and proinsulin degradation}

Insulin degradation was monitored by production of low molecular weight products soluble in trichloroacetic acid (TCA). The incubation conditions were as follows: $50 \mu l$ citrate/BSA $/ \mathrm{Zn}^{++}$buffer, pH 5.0, containing tracer ${ }^{125}$ I-insulin (with or without unlabelled insulin), or labelled insulin crystals, and $10 \mu \mathrm{l}$ lysosomal enzyme solution (diluted with citrate/BSA to obtain an aryl sulfatase activity of approximately $3 \mathrm{U} / \mathrm{ml}$ ). After set times at $37^{\circ} \mathrm{C}$ the reaction was stopped with $0.40 \mathrm{ml}$ ice-cold citrate buffer $(5 \mathrm{mg} / \mathrm{ml} \mathrm{BSA})$ and $0.5 \mathrm{ml} \mathrm{10 \%} \mathrm{TCA}$. The samples were centrifuged for $10 \mathrm{~min}$ at $2,000 \mathrm{~g}$ and the supernatants decanted. Radioactivity in the supernatant was considered to represent TCA-soluble degradation products. Two non-specific controls were included for all conditions: (1) addition of TCA at $0 \mathrm{~min}$, and (2) incubation under standard conditions without any addition of enzyme. No significant degradation was observed with time in the absence of enzyme. TCA-soluble products in the initial preparation amounted to $<2 \%$ total radioactivity.

For studying proinsulin degradation, human $\mathrm{A}^{14}$-mono- ${ }^{125} \mathrm{I}$ proinsulin (specific radioactivity $210 \mu \mathrm{Ci} / \mu \mathrm{g}$ ) was used as the substrate. The assay conditions were the same as for ${ }^{125} \mathrm{I}$-insulin. An alternative method was, however, found necessary for monitoring ${ }^{525} \mathrm{I}$-proinsulin degradation. Samples were subjected to sodium dodecyl sulfate/polyacrylamide gel electrophoresis under reducing conditions using a discontinuous system ( $20 \%$ acrylamide resolving gel) at $\mathrm{pH} 8.5$ [12]. After drying, the gels were exposed to Kodak XAR5 film to visualize the position of radioactive products. The disappearance of radioactivity from the position characteristic of native proinsulin was taken as an index of degradation. For insulin, TCA precipitation
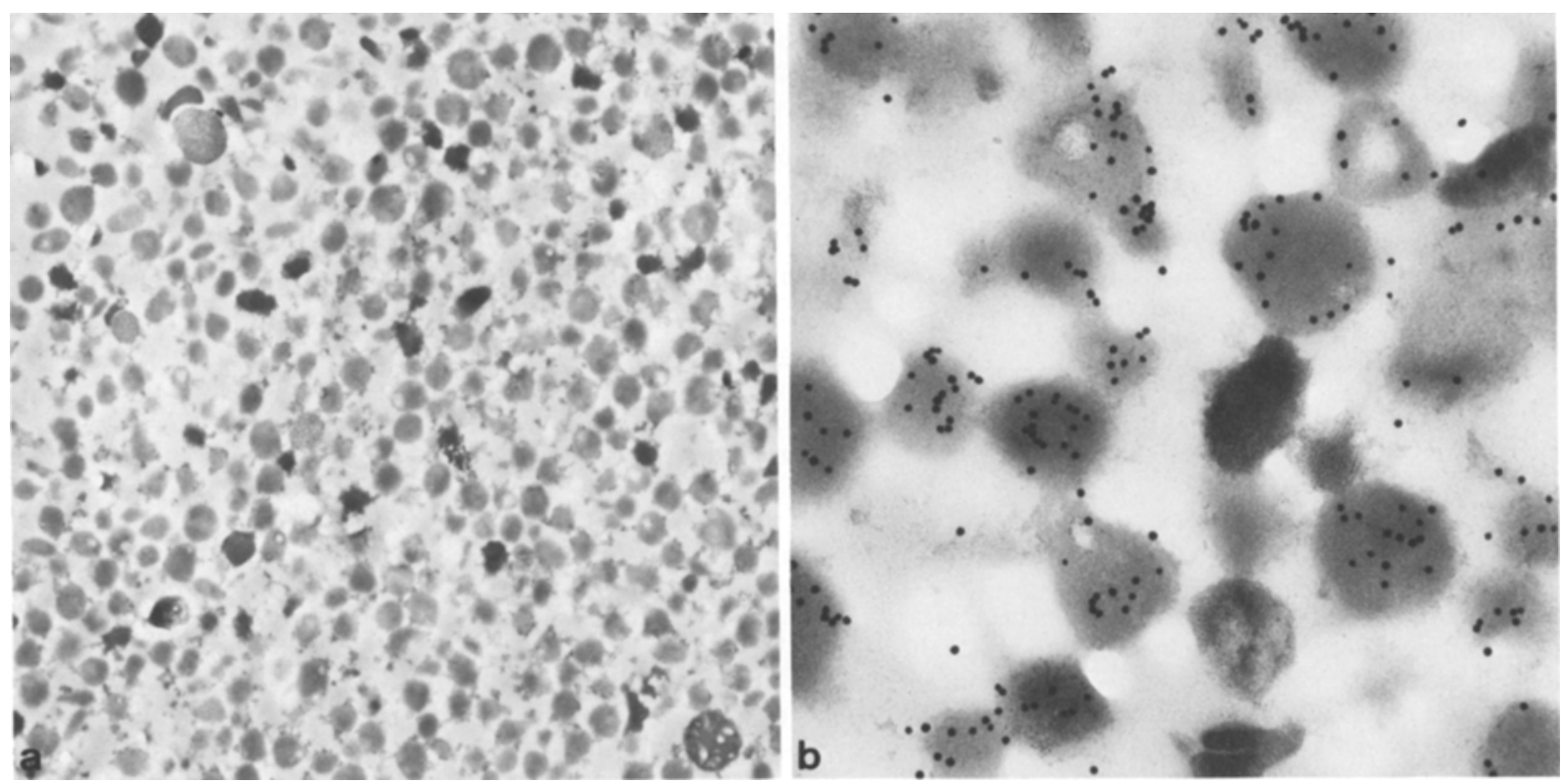

Fig. 1 a and b. Morphological assessment of liver lysosomes. a Thin section of purified rat liver lysosomes with some mitochondria and peroxisomes as contaminants $(\times 8,000)$. b Immunoreactive labeling (protein A-gold technique) of purified lysosome with cathepsin B antiserum $(\times 42,000)$. Lowicryl $\mathrm{K}_{4} \mathrm{M}$ low temperature embedding 


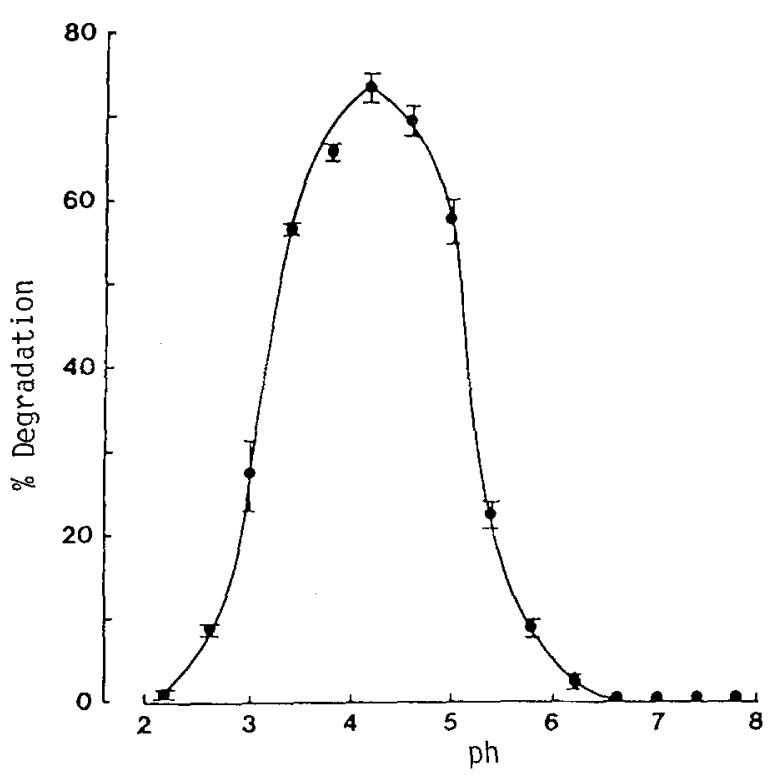

Fig. 2. pH-dependence of insulin degradation by lysosomal enzymes. Soluble ${ }^{125} \mathrm{I}$-insulin $(137 \mathrm{pg} / \mathrm{ml}, 50 \mathrm{nCi} / \mathrm{ml})$ was exposed to lysosomal enzymes $(0.5 \mathrm{U} / \mathrm{ml}$ aryl sulfatase activity) for $30 \mathrm{~min}$ at $37^{\circ} \mathrm{C}$ at the given $\mathrm{pH}$. Degradation was assessed by measuring production of radioactive products which were soluble in trichloroacetic acid. Data expressed as mean $\pm \operatorname{SEM}(n=4)$

Table 1. Effects of $\mathrm{Ca}^{++}$and $\mathrm{Zn}^{++}$on insulin degradation by lysosomal proteases

\begin{tabular}{ll}
\hline Assay conditions & $\begin{array}{l}\text { \% }{ }^{125} \text { I-insulin } \\
\text { degraded in } 30 \mathrm{~min}\end{array}$ \\
\hline Control & $22.7 \pm 0.06$ \\
$1 \mathrm{mmol} / 1 \mathrm{Ca}^{++}$ & $17.6 \pm 0.7$ \\
$10 \mathrm{mmol} / 1 \mathrm{Ca}^{++}$ & $14.9 \pm 0.4$ \\
$0.75 \mathrm{mmol} / 1 \mathrm{Zn}^{++}$ & $22.9 \pm 2.5$ \\
$7.5 \mathrm{mmol} / \mathrm{/} \mathrm{Zn}$ & $20.4 \pm 2.8$ \\
\hline
\end{tabular}

${ }^{125} \mathrm{I}$-insulin $(137 \mathrm{pg} / \mathrm{ml}, 50 \mathrm{nCi} / \mathrm{ml})$ was incubated at $37^{\circ} \mathrm{C}$ in citrate $/$ BSA buffer ( $\mathrm{pH} 5.0$ ) for $30 \mathrm{~min}$ in the presence of lysosomal enzymes $(0.5 \mathrm{U} / \mathrm{ml}$ aryl sulfatase activity). Non-specific degradation was estimated by incubating under the same conditions without addition of the enzyme solution. Results (mean \pm SEM, $n=4$ ) are expressed as total degradation less the non-specific (which was $<10 \%$ of total for all conditions)

Table 2. Dimension of microcrystals

\begin{tabular}{lc}
$\begin{array}{l}\text { Maximum dimension } \\
(\mu \mathrm{m})\end{array}$ & $\begin{array}{l}\text { \% Crystals with } \\
\text { given dimension }\end{array}$ \\
\hline $7-27$ & $58 \pm 2.8$ \\
$28-55$ & $20 \pm 2.3$ \\
$56-82$ & $12 \pm 3.0$ \\
$83-110$ & $2.8 \pm 0.6$ \\
$111-192$ & $3.5 \pm 1.8$ \\
$>192$ & $4.3 \pm 1.8$ \\
\hline
\end{tabular}

Microcrystals were examined by light microscopy $(400 \times$ magnification) using a grid for sizing. Each crystal was measured to obtain the length of its longest face (maximum dimension) expressed in microns. Four independent observations were made (the results being expressed as the mean of these four experiments). For each observation, $60-70$ crystals were measured. The crystals were then grouped according to size and the number of crystals falling in each group expressed as a percentage of the total population. Percent of crystals with a given dimension expressed as mean $\pm \operatorname{SEM}(n=4)$ and gel electrophoresis gave identical rates of apparent degradation, whereas for proinsulin it was found that TCA precipitation underestimated degradation by up to $80 \%$ (particularly at early time points).

\section{Results}

\section{Characterization of lysosomes and lysosomal proteases}

The purification of lysosomes was assessed both morphologically and by enzyme assay. The specific activity of aryl sulfatase in the initial liver homogenate was $0.05 \mathrm{U} / \mathrm{mg}$ total protein (where $1 \mathrm{U}$ is defined as $1 \mu \mathrm{mol}$ p-nitrocatechol sulfate hydrolyzed $/ \mathrm{h}$ ). The activity in the lysosome lysate was $7.2 \mathrm{U} / \mathrm{mg}$ protein amounting to a 144-fold enrichment in this enzyme. The yield of aryl sulfatase in the final lysosomal fraction relative to the initial liver homogenate was $8.3 \%$.

Examination of random thin sections of the pellet by transmission electron microscopy revealed an homogeneous population of well preserved lysosomes (Fig. 1a). A characteristic lysosomal enzyme (cathepsin B) could be demonstrated by immunocytochemistry on this population (Fig.1b). A few peroxisomes and some mitochondria were found as occasional contaminants (Fig. 1 a).

Lysosomal proteases are known to display an acidic $\mathrm{pH}$ optimum. Insulin degradation was therefore monitored over a wide $\mathrm{pH}$ range (Fig.2). Maximum activity was observed at $\mathrm{pH} 4.2$ with no detectable activity above $\mathrm{pH}$ 6.6. All subsequent assays were performed at $\mathrm{pH} 5.0$, which is thought to be close to the $\mathrm{pH}$ within intact lysosomes. At $\mathrm{pH} 5.0$, insulin degradation was $79 \%$ of the maximum observed at $\mathrm{pH} 4.2$ (Fig. 2).

Since the insulin crystal is stabilized in the presence of divalent cations, the effects of $\mathrm{Ca}^{++}$and $\mathrm{Zn}^{++}$on insulin degrading activity were also examined. Whereas 1 and $10 \mathrm{mmol} / 1 \mathrm{Ca}^{++}$resulted in a concentrationdependent inhibition of insulin degradation (Table 1) to $66 \%$ of control, $\mathrm{Zn}^{++}$at $7.5 \mathrm{mmol} / 1$ (the concentration used to prepare and subsequently stabilize the insulin $\mathrm{Zn}$-hexamer) had no inhibitory effect (Table 1 ). $\mathrm{Zn}^{++}$at $7.5 \mathrm{mmol} / 1$ was therefore included in subsequent assays.

\section{Characterization of insulin crystals and microcrystals}

$\mathrm{A}^{14}$-mono ${ }^{125} \mathrm{I}$-insulin was cocrystalized with native insulin to form labelled $\mathrm{Zn}$-hexameric crystals. The crystals were then disrupted to prepare a microcrystalline suspension. The microcrystals were examined optically. Although very small, they exhibited clear birefringence which appeared typical of rhombohedral crystals. Given the chemical history of these microcrystals, it is concluded that the preparation consisted of the $2-\mathrm{Zn}$ rhombohedral form. The microcrystals were sized under a light microscope by measuring the maxi- 


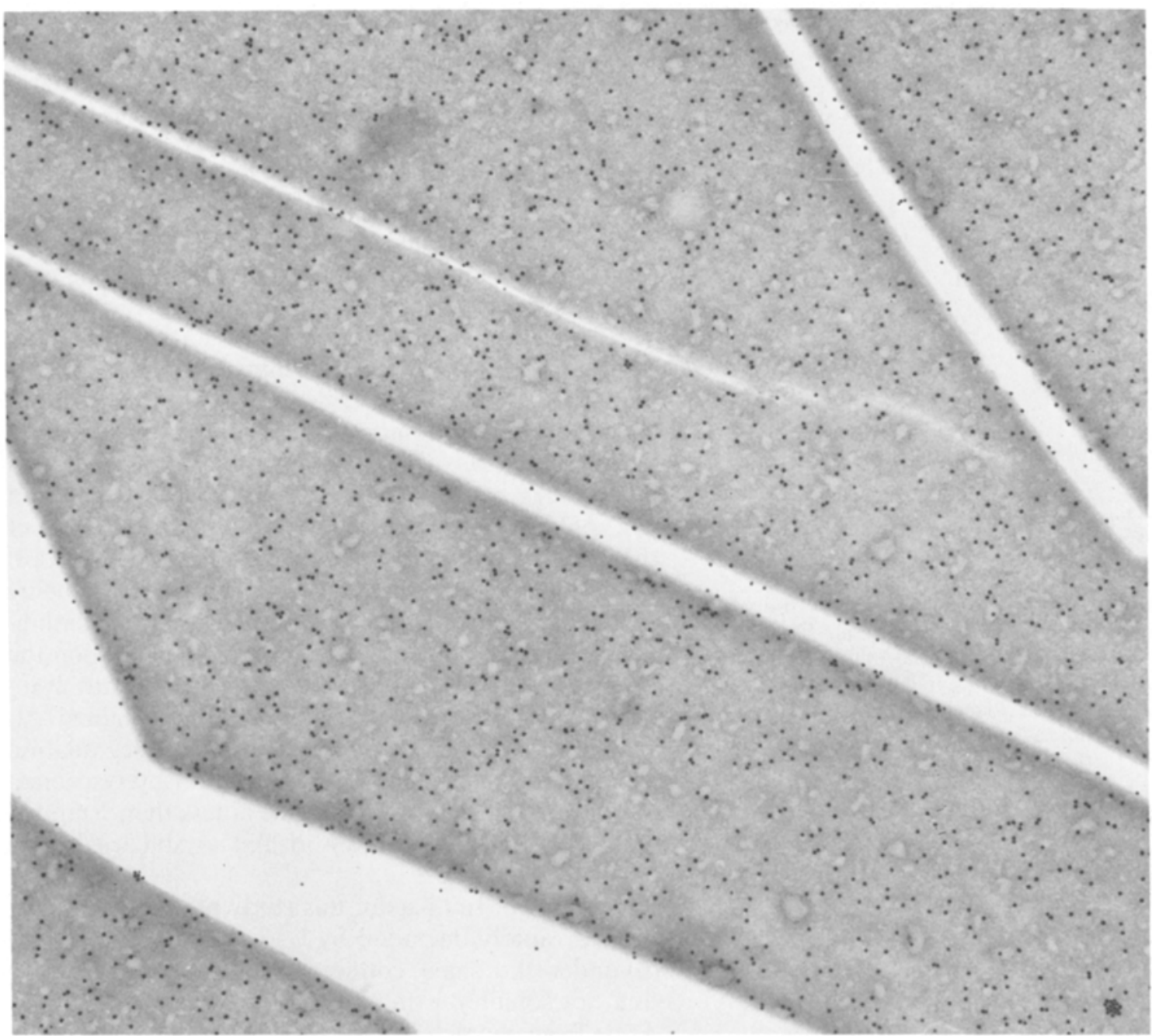

Fig. 3. Thin section of insulin crystals grown in vitro. Immunostaining with anti-insulin serum and protein A-gold $(\times 22,500)$. Lowicryl $\mathrm{K}_{4} \mathrm{M}$ low temperature embedding

mum dimension of each crystal fragment. As shown in Table 2, $90 \%$ of the crystals examined had a maximum face length of $<82 \mu \mathrm{m}$. Unlabelled crystals were also examined by electron microscopy and immunocytochemistry. Using anti-insulin serum, insulin antigenic sites were localized to the crystal face using the protein A-gold technique (Fig.3). The appearance of insulin in situ within $\beta$-granules following similar immunocytochemical analysis is comparable [6], suggesting that the antigenic sites recognized by this serum are accessible on the cut crystalline face whether in $\beta$-granules or in the chemically prepared crystals.

\section{Degradation of soluble insulin or proinsulin and insulin crystals}

The degradation of ${ }^{125} \mathrm{I}$-insulin and ${ }^{125} \mathrm{I}$-proinsulin was compared by incubation of these labelled peptides with the lysosomal enzyme preparation at $\mathrm{pH}$ 5.0. During the course of a 60 -min incubation at $37^{\circ} \mathrm{C}$, there was no apparent difference in the rates of degradation of insulin or its precursor (Fig.4). For these experiments, insulin was used in soluble form.

The rates of degradation of soluble insulin and of the microcrystals were then compared. The specific radioactivity of the soluble insulin was adjusted (by addition of unlabelled insulin to the tracer) to that of the microcrystals $(182 \mathrm{nCi} / \mathrm{mg})$. The total concentration of insulin for both the soluble and crystalline materials was $10 \mu \mathrm{g} / \mathrm{ml}$. The rate of degradation of soluble insulin at this concentration was similar to that observed for tracer quantities $(137 \mathrm{pg} / \mathrm{ml})$ (compare Figs. 4 and 5). The degradation of the crystals was extremely slow compared to that of the soluble material (Fig. 5). The initial rate of degradation for the soluble insulin was $1.94 \pm 0.04 \mathrm{pmol} / \mathrm{min}$ and for microcrystals $0.21 \pm 0.02 \mathrm{pmol} / \mathrm{min}$.

\section{Discussion}

Proinsulin and insulin display different physico-chemical properties which have been suggested to play a role 


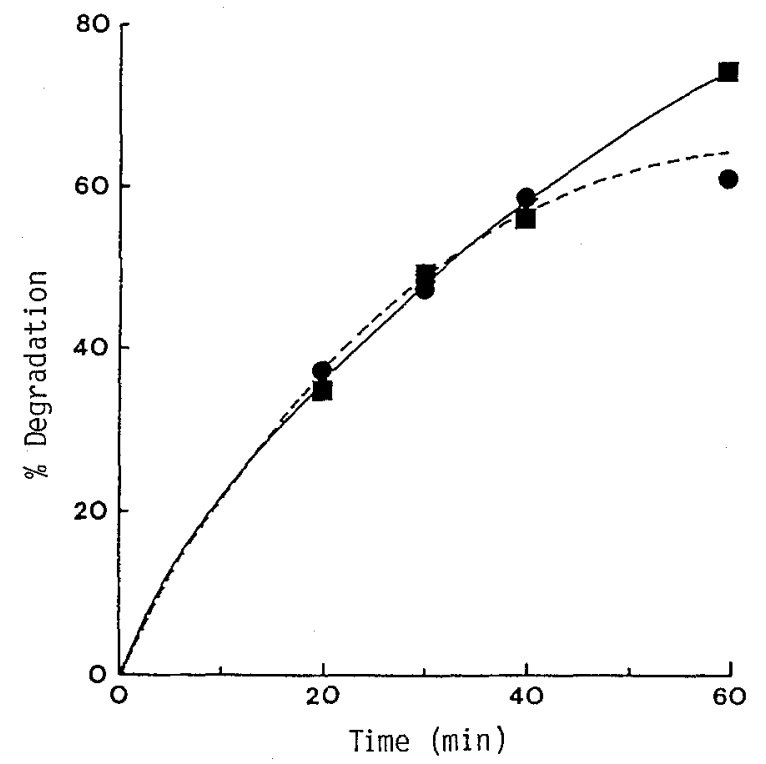

Fig.4. Degradation of soluble insulin vs. proinsulin. ${ }^{125} \mathrm{I}$-insulin $(137 \mathrm{pg} / \mathrm{ml}, 50 \mathrm{nCi} / \mathrm{ml})$ or ${ }^{125}$ I-proinsulin $(238 \mathrm{pg} / \mathrm{ml}, 50 \mathrm{nCi} / \mathrm{ml})$ were exposed to lysosomal enzymes $(0.5 \mathrm{U} / \mathrm{ml}$ aryl sulfatase activity) at $\mathrm{pH} 5.0$ and $37{ }^{\circ} \mathrm{C}\left(7.5 \mathrm{mmol} / 1 \mathrm{Zn}^{++}\right)$. Degradation for both molecules was assessed by loss of the intact labelled product as judged by polyacrylamide gel electrophoresis...-- proinsulin; insulin

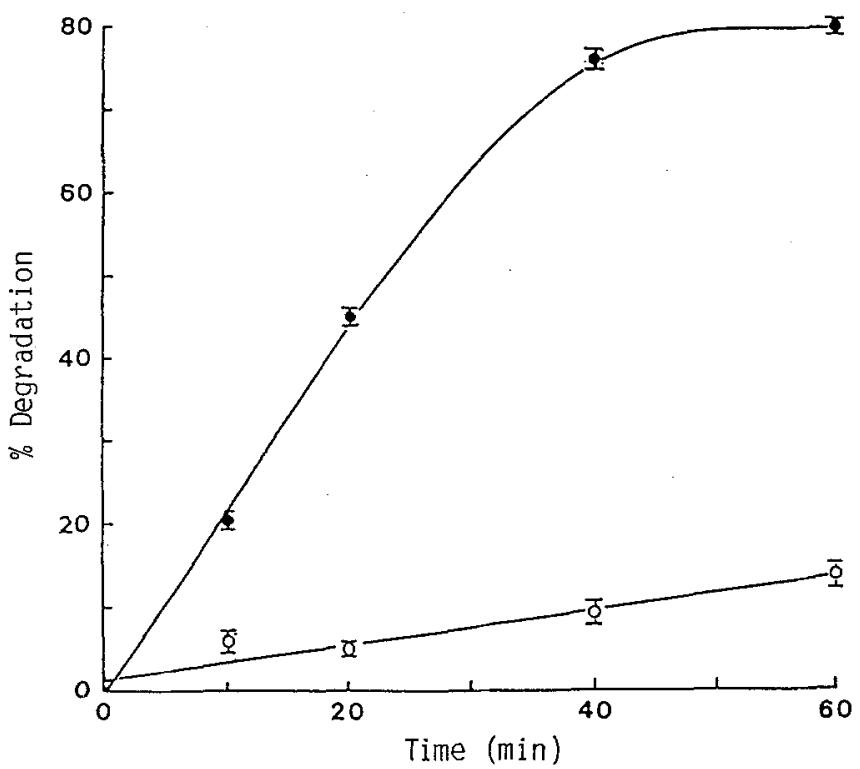

Fig.5. Degradation of soluble insulin vs. crystalline insulin. ${ }^{125}$ I-insulin in soluble or microcrystalline form was exposed to lysosomal enzymes $\left(0.5 \mathrm{U} / \mathrm{ml}\right.$ aryl sulfatase activity) at $\mathrm{pH} 5.0$, and $37^{\circ} \mathrm{C}$ $\left(7.5 \mathrm{mmol} / 1 \mathrm{Zn}^{++}\right)$. The total insulin concentration for each sample $(1.7 \mu \mathrm{mol} / \mathrm{l})$ and the lysosomal enzyme concentrations were similar for all samples. For degradation assay and expression of data, see legend to Figure 2. $\longrightarrow$ : Soluble insulin; $\mathrm{O}-\mathrm{O}$ : Crystalline insulin

in proinsulin processing by the B cell [13]. Of particular importance for this study is the observation that insulin hexamers, in contrast to those of proinsulin, are insoluble at acid $\mathrm{pH}$ in the presence of $\mathrm{Zn}^{++}[14]$ and that the $\mathrm{Zn}$-hexameric insulin crystal is remarkably stable at $\mathrm{pH} 4.6-6$ [13-15]. The stability of the insulin crystal at acid $\mathrm{pH}$ in the presence of $\mathrm{Zn}^{++}$is confirmed in the present study, since no soluble insulin was detectable even after a 2 -h incubation of the labelled microcrystals, at $37^{\circ} \mathrm{C}$ in the buffer used for degradation assays. The milieu within $\beta$-granules has been shown to be acidic $[16,17]$ and to be rich in $\mathrm{Ca}^{++} / \mathrm{Zn}^{++}[18,19]$. Both these conditions will favor insulin crystal formation and stability; this has been previously demonstrated experimentally [20,21]. Such is not the case for secretory granules which have fused with lysosomes during crinophagy. Although intra-lysosomal $\mathrm{pH}$ has been measured in intact cells to be as low as 4.75 [22, 23], the cationic composition of these organelles is largely unknown. Data demonstrating that lysosomal membranes are relatively impermeable to $\mathrm{Ca}^{++}$and $\mathrm{Mg}^{++}[24]$ suggest that the intra-lysosomal level of these ions may be low unless there are active transport systems not yet identified. In the event of $\mathrm{Ca}^{++}$being elevated within lysosomes, we should predict an inhibitory influence on insulin degradation based upon the present data. The $\mathrm{Zn}^{++}$concentration within lysosomes has not, to our knowledge, been determined. Although $\mathrm{Zn}^{++}$was not found to affect the degradation of low concentrations of soluble insulin by lysosomal enzymes, its absence (or presence at less than $1 \mathrm{mmol} /$ 1) would clearly render the insulin crystal less stable [13-15].

The major findings of this study are that (a) proinsulin is rapidly degraded by lysosomal proteases, and (b) under the same conditions insulin in crystalline (but not soluble) form is degraded remarkably slowly. Aside from characterization, in part, of the degradation of insulin and its precursor by lysosomal enzymes, these data may provide insight into their handling within the B cell. Clearly the in vitro system used in this study should not be assumed to be analogous to degradation within lysosomes in the $\mathrm{B}$ cell arising from crinophagy. The lysosomes used were from rat liver, not rat B cells (although they presumably house many if not all of the enzymes found in their B-cell counterparts). The composition of the assay buffer has already been discussed above, and the ratio of lysosomal enzymes to substrate may not be appropriate. Finally, the size of the microcrystals, although small by most criteria, is nevertheless 2-3 orders of magnitude greater than the estimated mean diameter of $180 \mathrm{~nm}$ of the putative crystals within $\beta$-granules [25]. Despite these reservations, certain parallels can still be drawn. We have previously shown that insulin, but not proinsulin/Cpeptide, can be localized within B-cell multigranular bodies (the product of lysosome- $\beta$-granule fusion) [6]. Furthermore, insulin, although degraded extensively within the B cell, is destroyed slowly [4] compared with rates of degradation observed for other hormones in their cell of origin [1]. Our present finding of slow degradation of insulin in crystal form in the face of rapid proinsulin degradation supports our hypothesis [6] that 
it is the protection of insulin in the crystal form, even after its introduction into lysosomes, which accounts for both its slow degradation in the B cell and its unexpected presence in multigranular bodies.

The consequences of a reduced rate of degradation of crystalline insulin may not, however, be of physiological consequence. Once introduced within lysosomes, the insulin is stable for some time according to our findings and as such is still presumably in a biologically active state. However, insulin within lysosomes, in contrast to that in granules, will not be released from the B cell in response to a physiological stimulus such as glucose. Insulin, once trapped within lysosomes, is thus no longer bioavailable despite retaining its potential activity. Insulin localized in lysosomes is, by contrast, likely to affect the significance of measurements of B-cell stores by conventional methods, since biologically active and bioavailable insulin (i. e. that in secretory granules) may not be distinguished from active yet unavailable insulin within lysosomes.

Acknowledgement. We thank Ms. D. Poczatek, A.Rosenstein and I. Bernard for typing the manuscript. We also thank Dr. B. Frank, Eli Lilly and Co., Indianapolis, for useful advice and encouragement in addition to his generous provision of ${ }^{125} \mathrm{I}$-insulin and ${ }^{125} \mathrm{I}$-proinsulin for these studies. This work was supported by grants from the Juvenile Diabetes Foundation, the National Institutes of Health (AM35292 and BRSG-507-RR-05673, P.Halban) and the Swiss Na* tional Science Foundation (3.404.86, L.Orci).

\section{References}

1. Bienkowski RS (1983) Intracellular degradation of newly synthesized secretory proteins. Biochem J 214: 1-10

2. Amherdt M, Orci L, Stauffacher W, Renold AE, Rouiller C (1970) Morphological evidence suggestive of an impairment of insulin secretion in vivo in normoglycemic spiny mice (Acomys cahirinus). In: Favard P (ed) International Congress for Electron Microscopy, Grenoble, France. Société Française de Microscopie Electronique, Paris, p 501

3. Creutzfeldt W, Creutzfeldt C, Frerichs H, Perings E, Sickinger K (1969) The morphological substrate of the inhibition of insulin secretion by diazoxide. Horm Metab Res 1: 53-64

4. Halban PA, Wollheim CB (1980) Intracellular degradation of insulin stores by pancreatic islets in vitro: an alternative pathway for homeostasis of pancreatic insulin content. J Biol Chem 255: 6003-6006

5. Smith RE, Farquhar MG (1966) Lysosome function in the regulation of the secretory process in cells of the anterior pituitary gland. J Cell Biol 31: 319-346

6. Orci L, Ravazzola M, Amherdt M, Yanaihara C, Yanaihara C, Halban P, Renold AE, Perrelet A (1984) Insulin, not C-peptide (proinsulin), is present in crinophagic bodies of the pancreatic B cell. J Cell Biol 98: 222-228
7. Ragab H, Beck C, Dillard C, Tappel AL (1967) Preparation of rat liver lysosomes. Biochim Biophys Acta 148: 501-505

8. Armbruster BL, Carlemalm E, Chiovetti P, Garavito RM, Hobot JA, Kellenberger E, Villiger W (1982) Specimen preparation for electron microscopy using low temperature embedding resins. J Microsc 26: 77-85

9. Roth J, Bendayan M, Orci L (1978) Ultrastructural localization of intracellular antigens by the use of protein A-gold complex. $J$ Histochem Cytochem 26: 1074-1081

10. Worwood M, Dodgson KS, Hook GER, Rose FA (1973) Problems associated with the assay of arylsulfatases A and B of rat tissues. Biochem J 134: 183-190

11. Schlichtkrull J (1961) Insulin Crystals. Thesis, University of Copenhagen, Denmark

12. Laemmli UK (1970) Cleavage of structural proteins during the assembly of the head of bacteriophage T4. Nature 227: 680-685

13. Emdin SO, Dodson GG, Cutfield JM, Cutfield SM (1974) Role of zinc in insulin biosynthesis. Diabetologia 19: 174-182

14. Grant PT, Coombs TL, Frank BH (1972) Differences in the nature of the interaction of insulin and proinsulin with zinc. Biochem J 126: 433-440

15. Blundell T, Dodson G, Hodgkin D, Mercola D (1972) Insulin: the structure in the crystal and its reflection in chemistry and biology. Adv Protein Chem 26: 279-402

16. Hutton JC (1982) The internal $\mathrm{pH}$ and membrane potential of the insulin-secretory granules. Biochem J 204: 171-178

17. Orci L (1985) The insulin factory: a tour of the plant surroundings and a visit to the assembly line. Diabetologia 28:528-546

18. Ravazzola M, Malaisse-Lagae F, Amherdt M, Perrelet A, Malaisse WJ, Orci L (1976) Patterns of calcium localization in pancreatic endocrine cells. J Cell Sci 21: 107-118

19. Hutton JC, Penn EJ, Peshavaria M (1983) Low-molecular-weight constituents of isolated insulin-secretory granules. Biochem J 210: 297-305

20. Coore HG, Hellman B, Pihl E, Täljedal I-B (1969) Physiochemical characteristics of insulin secretion granules. Biochem J 111: $107-113$

21. Howell SL, Tyhurst M, Duvefelt H, Andersson A, Hellerström C (1978) Role of zinc and calcium in the formation and storage of insulin in the pancreatic $\beta$-cell. Cell Tiss Res 188: 107-118

22. Roos A, Boron WF (1981) Intracellular pH. Physiological Reviews $61: 296-403$

23. Ohkuma S, Poole B (1978) Fluorescence probe measurement of the intralysosomal $\mathrm{pH}$ in living cells and the perturbation of $\mathrm{pH}$ by various agents. Proc Natl Acad Sci 75: 3327-3331

24. Reijingoud D-J, Tager JM (1977) The permeability properties of the lysosomal membrane. Biochimica et Biophysica Acta 472: 419-449

25. Greider MH, Howell SL, Lacy PE (1969) Isolation and properties of secretory granules from rat islets of Langerhans. II. Ultrastructure of the beta granule. J Cell Biol 41: 162-166

Received: 17 November 1986

and in revised form: 16 March 1987

Dr.P.A. Halban

Unité Jeantet

Centre Médical Universitaire

9, avenue de Champel

CH-1211 Geneva 4

Switzerland 